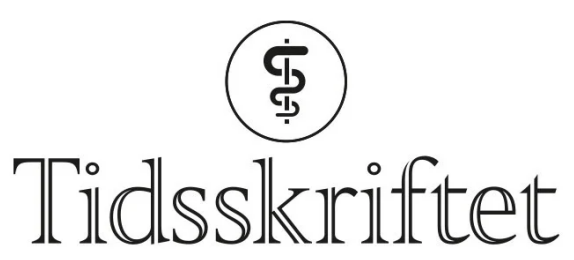

DEN NORSKE LEGEFORENING

\title{
Helse og sosial posisjon
}

\author{
ANMELDELSER
}

\section{BJøRGULF CLAUSSEN}

Prosjekt «storbyhelse»

Institutt for allmenn- og samfunnsmedisin

Universitetet i Oslo

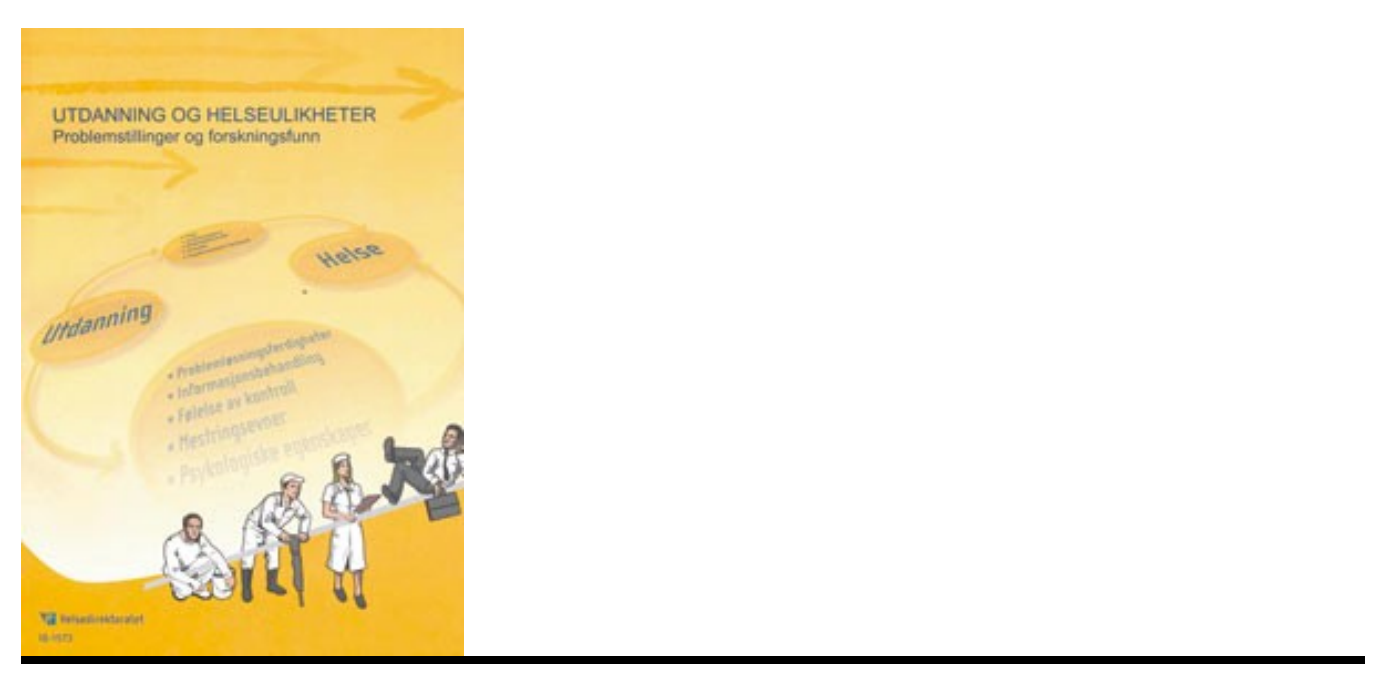

Elstad, JI.

Utdanning og helseulikheter

Problemstillinger og forskningsfunn. 148 s, tab, ill. Oslo: Helsedirektoratet, 2008. Gratis

IS-1573

Helsedirektoratets ekspertgruppe om sosiale ulikheter i helse har utgitt et hefte før, Gradientutformingen, som gir en svært kort innføring i temaet. Den foreliggende boken er en grundigere oversikt over sosial posisjon og en rekke helsemål. Den er skrevet av et medlem i gruppen, Jon Ivar Elstad, sosiolog ved NOVA (Norsk institutt for forskning om oppvekst, velferd og aldring). Han har forsket på dette temaet i mange år og viser her et solid grep om teori, forskningsresultater og metoder på feltet.

Utdanning er det målet han har valgt for sosial posisjon. Det er et vellykket grep, for i svært mange norske og andre vestlige studier har man brukt dette målet, som har god validitet både for unge voksne og senere i livet når det gjelder plassering i den sosiale lagdelingen. 
Helsemålene er mange, og Elstad viser klart og greit sammenhengen mellom dødelighet, somatisk og mental helse og utdanning hos så vel barn og ungdom som voksne. Enda bedre, han går gjennom en rekke mulige forklaringsmekanismer og større teorier om hvorfor sosial posisjon og helse henger sammen.

Utdanning og helseulikheter er uvanlig velskrevet. Språket er lett tilgjengelig, og figurer og tabeller er gjennomarbeidet. Den anbefales alle som vil ha en klar og forholdsvis kort innføring i sosiale ulikheter og helse.

Publisert: 12. februar 2009. Tidsskr Nor Legeforen. DOI: 10.4045/tidsskr.08.0681

(C) Tidsskrift for Den norske legeforening 2023. Lastet ned fra tidsskriftet.no 26. april 2023. 